could be mass-produced. Building materials and manpower are provided by the country itself and therefore would not create a commercial imbalance. Public transportation would reduce, to next to nothing, the needs for oil and cars. The regrouping of habitations would considerably reduce the cost for heating and air-conditioning. The linearity of the city would help in reducing the cost of numerous goods and services. One can think of the roads and their maintenance, of course, but also complex networks of distribution for natural gas, electricity, sewers, cable, and telephone, mail, etc. Industries would also find it easier for their installations and the distribution of their products. The cost of governmental services would also be reduced with linearity and this would reduce the taxes.

On the ecological side, the lesser oil consumption would certainly help a great deal in reducing the 'greenhouse' effect while preserving this limited resource. A scientific conference held in Toronto in 1988 issued the recommendation of a $20 \%$ reduction of all carbon emissions by the year 2005 . The substantial reduction in the use of land would reduce imposition on the food-chain, reduce the desertification and other loss of agricultural lands, and improve the oxygenation of the planet. The selective garbage collection of recyclable materials could be simplified easily by different drops linked to wagons that would be directly brought to the recycling plan.

As for our current industrial parks, industrial activities would be regrouped close to the public transportation system, to set them apart from the residential areas. Their access to their markets and specialized workers would be improved, so that virtually no land would be needed for parking. This regrouping in height and on the ground would make it possible for industries to share common services. For instance, they could reduce their sources of pollution by having common filtration systems for smokestacks and used waters. This proximity between industries would greatly facilitate communications, while taking into account current technologies and other relevant factors; nevertheless some planning would be needed to bring together those who collaborate the most with one another.

\section{Improving Security and Life}

Security would also be improved, due to the links between buildings that would facilitate the evacuation of high-rise buildings in case of fire. A central surveillance for each module would have cameras installed at strategic points to insure prompt seeking of help. For its arrival underground roads would be reserved for emergency services. An integrated fire-fighting system, combined with a fireproof construction, would considerably reduce the damage and any loss of lives caused by fire. The public transportation system would make car accidents practically a thing of the past.

The plans and documents describing this project only give information about the architectural side of it by describing its functioning, the dimensions, and an analysis of the main elements. Much room has been left to allow for differences in the frontages, the inner halls and parks, apartments, and public buildings out of the city. It is best to leave that to the local governments and communities to offer the pleasantness of diversity. The reduction in built areas should justify architecture of high quality and could even increase the need for architects who are not accustomed to public employment nowadays. It goes without question that it is also important to keep those buildings that have architectural or historical values.

I strongly believe that the Linear City brings an interesting and realistic solution to problems that our society has to address, and more and more drastically as time goes on. Gradually, our present cities will be replaced by others that should be more suitable for the present and future needs of humanity. Certain countries must build new housing urgently to answer those needs. If we do not want to leave irreversible situations to future generations but instead a better world. a remediatory project such as the Linear City must be started as soon as possible.

\section{GILlES GAUTHIER, Architect CPO 775 Station C Montreal P.Q., Canada.}

\title{
Tourism Development in Bay of Bengal Islands: Problems and Prospects
}

$\mathrm{T}$ he Andaman and Nicobar Islands, a Union Territory of India, are situated in the Bay of Bengal at $6^{\circ}$ to $14^{\circ} \mathrm{N}$ and $92^{\circ}$ to $94^{\circ} \mathrm{E}$. They comprise a total of 572 islands, islets, and rocks; have a total geographical area of $8,293 \mathrm{sq} . \mathrm{km}$ and total coastline of $1,962 \mathrm{~km}$; and are $1,200 \mathrm{~km}$ away from the Indian mainland. Moreover, Nature has endowed these humid tropical islands with one of the world's richest ecocomplexes of forest, mangrove, and marine vegetation complexes.

Long isolation and undisturbed ecology favoured the development of unique insular fauna $(5,300$ species of major animals) and flora (1,500 species of angiosperms) and has harboured irreplaceable gene-pools of many interesting endemic animals and plants, confining them to some specified areas with Indo-Chinese and IndoMalayan elements.

The islands are still also the home of primitive aboriginal tribal people belonging to the Nigrito (four) and Mangolian (two) races. Ross Island - a ruined complex and settlement, Viper Island - gallows and jail (Mount Harriet, Cellular jail - a national memorial) are historical relics of about 100 years (1858-1947) of occupation of the British regime; there is also a Shinto Shrine built during the Japanese occupation of 1942-45.
The natural, tribal, and historical, heritage offer tremendous scope for Nature and adventure tourism in these islands. The Andaman and Nicobar Administration, after the declaration of 'tourism' as an industry in 1987, initiated tourism development with the Ministry of Tourism as the nodal authority to cope with foreign currency and to generate employment, particularly in 1993.

Andaman Water Sports Complex, Mini Disney Land cum Amusement Park, Sound and Light show, adventure tourism facilities, accommodation (1,380 beds), beautification of the capital city Port Blair, and tourism festival in February, are the latest developments. To boost tourism during 1995-96, many islands are being opened for foreign tourists and planned funds are doubled to complete the projects of marine aquarium cum dolphinarium, setting of golf course, purchasing house boats, speed boats, $\mathrm{A} / \mathrm{C}$ coaches, providing more accommodation, and extension of the runway of the present airport to link these islands with nearby South-East-Asian countries.

Environmental degradation started in 1858 with the penal settlement and was sustained until 1947. The postindependent schemes of settlements, immigration, agriculture, agroforestry, wood-based industries, etc., intensified in the recent past and had seriously affected the fragile and sensitive ecocomplexes of these islands. 
The present population of 0.3 million has already exceeded the carrying capacity of the islands. The scarcity of drinking water, electricity, food commodities, transport, and subsidies in various sectors, are the major constraints of permitting mass tourism. However, Nature and adventure-upmarketing ecofriendly package tourism can be developed, though only after careful consideration of deforestation, soil and coastal erosion, disposal of nonde- gradable wastes, and due sanitation to conserve and preserve indispensable biodiversity for future generations.

T.C. KHATRI
GC-3, Government College Colony
Port Blair 744104
Andaman Islands
India.

\section{International Energy Foundation}

$\mathrm{T}$ he International Energy Foundation (IEF) was formally established in 1989 as a non-profit organization having the main objective of fostering world education and scientific research on all aspects of energy production, management, distribution, conservation, and use -- with one of the emphases being on renewable sources of energy and the environment. The Foundation is the outcome of a series of recommendations from representatives of more than 70 countries who participated in the international energy 'Energex' forums in 1982, 1984, and 1988. IEF's main mission is to facilitate the trans ler of the benefits of research and technology in all areas of energy, with special emphasis on renewable sources among emerging nations.

IEF has an international Board of Directors from 10 countries, who bring.a global perspective to our operation. We have also established regional headquarters for Eastern Europe (Moscow), the Middle Filst (Bahrain), Northern Africa (Egypt), North America (Regina), and Australia (Canberra). Others will be announced as they are established in due course.
We are currently in the final stage of development for Energex '96 (Beijing) and the early stages for Energex '98 (Bahrain) and Energex AD 2000 (Palm Springs). More recently the 1993 Seoul Resolutions (an outcome of Energex ' 93 ), approved by the Board of Directors, resulted in the planned establishment of the Foundation's world headquarters in Geneva, Switzerland, to serve IEF's 8.000 contacts in more than 75 countries'.

If you would like to participate in sharing knowledge in this vital field with the rest of the world, please write to the undersigned:

PETER J. CATANIA (Prof. Dr), Chairman
International Energy Foundation
I777 Victoria Avenue
Regina
Saskatchewan S4P $3 C 4$
Canada

Fax: (1 306) 7818364.

\section{The London Environment Centre}

\section{Background}

'The environment' as a topic hals permeated almost all areas of working life and has developed far beyond the traditional Nature conservation aspects such as species survival and habitat maintenance. However, Nature conservation measures taken at local level may have limited effects, set against the environmental changes brought about by larger-scale phenomena such as acid rain, global warming, and stratospheric ozonc depletion. The realization of the link between macro-kevel activities in cities, factories, and the built environment in general, and their profound effect on the species and habitats we seek to preserve at local level, is resulting in programmes of action as the 'act locally, think globally' maxim gathers momentum.

Consequently, there is an urgent need to raise the level of environmental awareness of decision-makers, business, and industry, as well as of governments, to encourage positive environmental action. However, efforts directed towards this end have not always met with success. Perhaps only increasing legislation and the possibilities of severe penalties will make organizations in both public and private sectors begin to take serious account of the environmental impact of their actions.

\section{Numerous EU Environmental Dirctives}

There are now over 300 Europcan Union (EU) Directives concerning the environment in addition to National and local legislation in individual countries. In the manner of every country in the EU, the UK has passed legislation both to implement pertinent EU Directives and to support its own environmental policies. The government has stated that its commitment to sustainable development will result in more restrictive environmental legislation being enacted in future. This, and the financial and other consequences of failing to comply with environmental legislation, have finally resulted in a higher profile for environmental matters in a wide range of organizations. However, the Small and Medium Enterprise (SME) sector remains largely unaffected by environmental considerations. This may be as a consequence of the impact of the recession and of ongoing financial problems in this sector.

Another factor in the heightened profile of environmental matters is increasing public environmental awareness, which has caused the environment to enter the agenda of most of the major political parties in Europe. The general public now have an expectation of positive measures from governments to improve living conditions through measures aimed at protecting and improving the environment. Consumer power is also acting to influence the environmental standards of goods, services, and manufacuring processes, although mechanisms for disseminating accurate environmental information to the public are not fully effective.

\section{Environment an Integral Part of Business}

The fundamental change in thinking that has occurred over the past few years has been to view the environment as an integral consideration to all business operations and activities. Indeed, the essence of sustainable development as promoted at the Rio Summit was not to put the brakes on economic growth and development (which was previously the main tone of the 'environmental' message); rather that 